\title{
第32回福井学術大会 ワークショップ
}

\section{研究委員会ワークショップ}

第32回社団法人全日本鍼炎学会学術大会の前日に, 研究委員会（旧鍼炎研究 ワーキング・グループ）は，下記の要項でワークショップを開催した。

第一部 日時 昭和 57 年 6 月 4 日 午後 1 時

場所 福井市文化会館 4 階大会議室

第二部 日時 昭和 57 年 6 月 4 日 午後 6 時

場所 芦原温泉「ニュー芳泉荘」

○内 容

第一部 診察室拝見

——銊治療の客観的効果判定のための統一カルテの使い方の実際—— 司会 熊澤孝朗

I -1 肝機能障害

黒 野 保三

(p 92 )

I -2 高血圧症

蟹 江勝

(p 93 )

I -3 腰痛症

山田勝弘

(p 97 )

I -4 膝痛症

北出 利 勝

(p100)

\section{第二部＼cjkstart臨床経験から観た経穴}

——経穴部位の特徵は？ 非経穴部位との違いは？-

司会 高木健太郎
II -1
池田太喜男
(p108)
II -2
岸勤
(p110)
II -3
福島弘道
(p111)

(ㅇ)(社) 全日本銊炎学会

研究委員会事務局

担当 石 神 龍 代

テ460 名古屋市中区新栄2-13 栄・第一生命ビル $2 \mathrm{~F}$

東洋医学研究財団付属銊尒院内 TEL. 052-971-1433 


\section{I -1 怚性肝機能障害患者の模擬治療室}

黒野 保三

慢性肝機能障害患者に銊治療を施し，その有効性を検 討することは，非常に困難なことと思われる。しかし， 銊尒医学が古来より内経医学として受け継がれてきた ことから「慢性肝機能障害疾患」にアプローチを加え ることは，必ずしも不自然ではない。すでに我々は， DDY 系雄マウスを使用した四塩化炭素による肝障害 に対する，鍼治療の有効性を検討した。基礎的研究を はじめ, 臨床面でも少数例ではあるが,「慢性肝機能障 害疾患」に対する銊治療の有効性も検討してきた。

前述の慢性肝機能障害患者に対する鍼治療を，会員 の方々に一人でも多く追試をしていただくために，模 擬治療室を試みた。

○例: A

患者：堀 茂 33歳 男性 会社員

主訴：倦怠感，食欲不振および背部痛

家族歴：父 昭和 49 年胃癌にて死亡, 母健在, 兄 2 人, 姉 2 人健在。

既往歴：なし

現病歴：生来健康で著患不知, 昭和 57 年 2 月中旬風 邪気味になり，軽度の倦怠感を覚え頭重感があった。 体温 $37^{\circ} \mathrm{C}$ であったが，休養をとらなかった。その他身 体の自発痛を認めず，4 月下旬頃も上記症状が同様持 続していたが，そのまま平常通り日常生活を続けた。

5 月20日頃より，食欲不振・吐気・不眠を覚えるよ うになり，終日倦怠感があった。その後，便・尿の外 観上の異常に気づくようになる。便は黄白色, 尿はビ 一ル色を呈していた。友人に勧められ，昭和57年 6 月 4 日来院。

来院時現症：六部定位脉診により肝虚を認む。脉状 は浮・濇・数を認めた。顔色やや黄色を呈す。皮膚に は特記すべき所見なし。

自覚症状：右背部および右悸肋部に鈍痛・食欲不振・ 終日倦怠感・不眠・全身に痒み感を訴えていた。

他覚的所見：右第 7 胸椎より第 10 胸椎間の胸最長筋 部に圧痛あり，右悸肋部より心窩部胸骨剣状突起下 3 $\mathrm{cm}$ 間に硬結を認める。肝は, 鎖骨中央線上, 肋骨弓下 2 横指触れる。四肢に異常なし。

治療計画

統一治療穴：肝兪・腎俞・太衝 - 右期門 - 中脘 - 気 海, 脉診による選穴：曲泉, 自覚症状・他覚的所
見による選穴：天柱・風池・肩井・上脘 使用銊：セイリン鍼, 1 寸 2 番

手技：単刺術

治療頻度：毎日または隔日

治療期間：6 月月間

理化学的検查：月に $1 \sim 2$ 回（採血時に自覚症状を カルテに記載)

治療後：慢性肝機能障害疾患の疑いのため, すみや かに医師の診察を受けるように指示をする。

例：Aの場合，自覚症状・他覚的所見により，慢性 肝機能障害の疑いを推測した。この場合, 初診時の自 覚症状を他覚的所見および現病歴を細かく記載する。 これは銊炎師が患者の病状を把握し，治療方針を決定 する上で重要であることは周知の通りである。最近, 日本肝藏学会においても自覚症状・他覚的所見を重要 視している。したがって，統一カルテの裏面にもれな く記載すること。証決定は，問診を始める前に行なう ことが望ましい。また，月に一回以上医師の診察を受 けるように指導する。

○例：B

患者：中村弘則 24 歳 男性 会社員 主訴：検查所見による不安感

家族歴：特記すべき事項なし

既往歴：なし

現病歴：生来健康で著患なし, 昭和 57 年 4 月上旬風 邪にて 2 日間休養。昭和 57 年 5 月 17 日, 社内の集団検 診受診, 血液検査で肝機能異常を指摘され, 精密検査 を指示されたが，鍼治療希望で昭和57年 6 月 4 日来院。 来院時現症：六部定位脉診により肝虚を認む。脉状 は浮・㵽を認めた。顔色及び皮膚には特記すべき所見 なし，自覚症状なし。腹診により，肝は鎖骨中央線上， 肋骨弓下にて一横指触知したが, 脾および胆囊には触 れず, 四肢に変形, 浮腫はなく, 神経反射に異常なし。 背部にて右側第 7 胸椎, 第10胸椎間の最長筋の硬結と 圧痛を認めた。

昭和 57 年 5 月 17 日の血液検査所見

$\mathrm{A} / \mathrm{G}$ 比 1.58 ・総ビリルビン $0.8 \mathrm{mg} / \mathrm{dl}$ ・直接ビリル ビン $0.42 \mathrm{mg} / \mathrm{dl} \cdot \mathrm{TTT} 6.4 \mathrm{U} \cdot Z \mathrm{ZTT} 15.4 \mathrm{U} \cdot \mathrm{GOT} 6.5 \mathrm{U} \cdot \mathrm{G}$ $\mathrm{PT} 80 \mathrm{U} \cdot \gamma-\mathrm{GTP} 60 \mathrm{U} \cdot$ 総コレステロール $233 \mathrm{mg} / \mathrm{dl} ・ コ リ$ ンエステラーゼ1.16 $\Delta \mathrm{PH}$ であった。

治療計画

統一治療穴：肝俞・腎兪・太衝 - 右期門 - 中脘 - 気

海, 脉診による選穴：曲泉

治療頻度：隔日または週 2 日 
治療期間： 6 名月間

使用鍼：セイリン鍼 1 寸 2 番

手技：単刺術

理化学的検査：月に $1 \sim 2$ 回（採血時に自覚症状を カルテに記載)

例：Bの場合，来院時に自覚症状を認めないため, 触診を行なうように心掛ける。後日自覚症状を覚える ことを考慮し，来院時には問診に気をつけること。

重症度判定と効果判定については，機会を得て説明 したい。

「慢性肝機能障害カルテ」は p 95，p 96を参照。

（干464 名古屋市千種区春岡通4-16）

\section{I -2 高血圧症に対する問診例}

蟹江 勝

$\mathrm{O}$ さん(45)は，C社総務課に勤務するビジネスマン。 体格は長身で中年肥りが現われ始めてきた。性格は外 見に似合わず細かい神経の持ち主。酒，タバコはたし なむ程度。

1 年前に一度, 項部がコルといって来院する。カル テには 3 回の施療で治癒になっている。

銊菼師「今日はどうされましたか」

$\mathrm{O} 「 2$ 週間ほど前から午後になると,頭が重く頭 痛がしたり，眼の奥がいたむようで，仕事がは かどりません」

鍼炎師「何か治療を受けていますか」

O「「かかりつけの内科で診察を受けました。先生 は，血圧が少し上っていますが，いつもの一時 的な高血圧でしよう。頭痛との関連はないとい われました。安定剤の投与を受け，しばらく様 子をみておりましたが，スッキリしませんので 来ました」

鍼炎師「悪心, 嘔吐はありませんか。夜眠むれますか」

O「「別にありません。熟睡はできませんが」

鍼炎師「痛み方はどんな感じですか。痛む場所は」

$\mathrm{O} 「$ 重くて時々頭のまわりが締めつけられる痛み です。頭を持ち上げると痛みが強くなる時もあ

ります。後頭部から額にかけてつらいです」

銊炎師「過去に頭部外傷を受けたり，眼，鼻，歯に異 常などありませんね」

O「「りません。私の経験ですと, 会議が続いた り神経を使いすぎたり夜更かしが続くと, 頭痛 が起ってくるようです。頸，肩のコリも感じま す」

鍼炎師「Oさんの頭痛は 項部 後頭部の筋収縮に伴 う緊張性頭痛のようです。頭痛は主に頭蓋内組 織の異常を知らせてくれる一種の危険信号の役 目もあり，頭痛ぐらいといって，安易に取り扱 わないことです」

O「そうですか。気をつけます」

銊炎師「先程血圧が上っているといわれましたが, 数 值聞いておりますか」

O「「之，最高が165で最低が90です。いつも 3 〜 4 回診察を受けると, 最高が150前後に安定し ます。最低は変りません」 
鍼尒師「降圧剂を服用しておりますか」

O「過去に 2 - 3 度血圧が異常に上った時だけ飲 みました。常には飲んでおりません」

鍼炎師「内科ではいろいろ検査を受けたと思います。 心電図，胸部 $\mathrm{X}$ 線，眼底検查，血液，尿検査な どの結果はどうでしたか」

$\mathrm{O} 「$ 時々検査を受けます。高脂血の傾向は見られ るが，他は心配する異常は現われていないと聞 いております。塩分, 脂肪の捸取過多は注意し なさいと」

銊炎師「高血圧を知ったのは，いつ頃ですか」

$\mathrm{O} 「$ 数年前です。会社の検診で指摘され, 医師の 診察を要すると告げられた時は, ショックをう けました。早速内科へ行きました。先生は, 少 し経過を見る必要はあるが，一時的な高血圧で あろうといわれ，それ以後血圧に関心を持つよ うになりました」

鍼炎師「高血圧は重症なものを除けば, 自覚症状が現 われにくいと, 循環器の専門家は注意を促して おります。少しぐらい血圧が高くても，日常生 活になんら支障がないので検診が重要です」

$\mathrm{O} 「$ 私の母親も高血压で, 長年医者にかかってい ます。高血圧は遺伝するのですか」

銊炎師「高血圧症を簡単にいえば,他に病父があって 血圧の上るものを二次性高血圧症，そうではな い原因が不明なものを，本態性高血圧症といい ます。高血圧症の90\%程度は本態性のものです。 また，本態性は遺伝が強く影響し，家族発生率 は多くの報告において70\%前後の值を亦してい ます。

O「「私の場合はどうですか

鍼炎師「Oさんは，平均的最高血圧が150前後。最低 が90前後ですね。WHOではこの付近の血压を 境界域血圧といい，将来高血压症に移行しや すいので，高血圧症子備軍みたいな存在ですね」

O「「どんなことに気をつけたらよいですか。銊卒 治療はどうですか」

銊尒師「塩分, 脂肪食, 夕バコは控之目に, 過食は肥 満につながります。それに環境因子の影響は強 いでしよう。過労，ストレスも蓄積しないよう に心掛けること。これらの種々の因子が自律神 経あるいはホルモン等に作用して血圧を上げる という研究発表もあります。鍼尒療法は自律神 経の調節，あるいは内臓諸機能に好ましい作用
を与えるので，高血圧症の予防管理には好まし いと考えられます」

O「「いろいろ話をうかがいますと, 高血圧は患者 の健康管理が大切ですね

銊尒師「そjです。高血圧をそのまま放置していると 将来心臟に負担をかけ, 脳卒中, 心筋梗塞, 腎 臟病のもとになる血管の病気を助長し，死に到 らしめることにもなり，〈どいようですが，日 頃から予防，管理には充分注意を意らないこと です。では，血圧を計って治療をしましよう」

O「よろしくおねがいします」

鍼尒師「こちらのべットへどうぞ…...」

(干476 東海市名和町南之山11-3) 


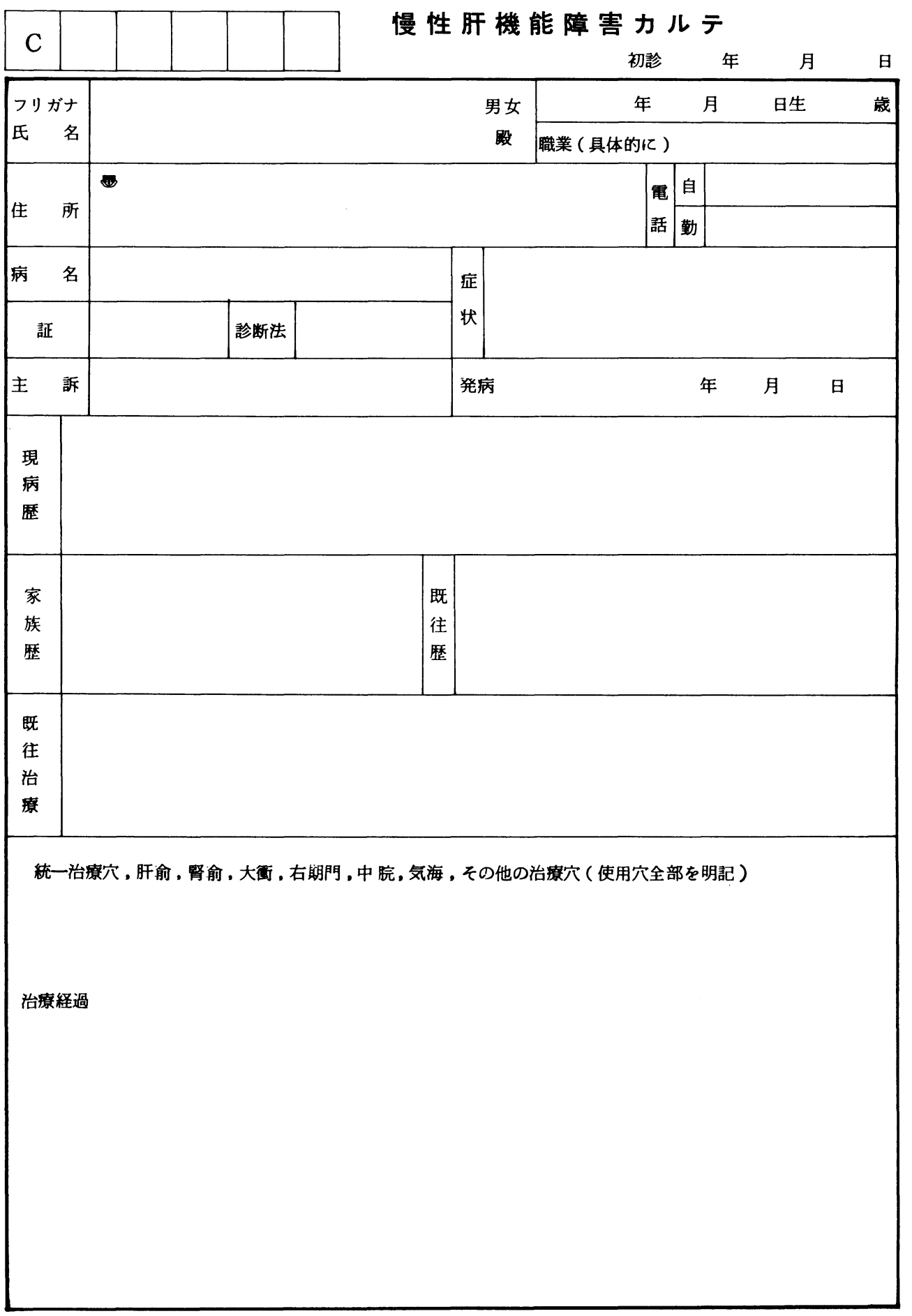


慢性肝機能障害カルテ裏面

証 $=$ 肝虚証

症例 B

\begin{tabular}{|c|c|c|c|c|c|c|c|c|c|c|c|c|c|}
\hline \multirow{2}{*}{\multicolumn{2}{|c|}{\begin{tabular}{|l|} 
効果判定 \\
初訏 \\
重症度判定 \\
\end{tabular}}} & & & 点 & 最終 & \multicolumn{4}{|r|}{ 点 } & \multicolumn{2}{|c|}{ 追跡 3 ケ月後 } & \multicolumn{2}{|r|}{ 点 } \\
\hline & & \multirow{2}{*}{\multicolumn{2}{|c|}{$\begin{array}{ll}2 & \text { 点 } \\
2 \text { 倍以下 }\end{array}$}} & 4 点 & 6 点 & \begin{tabular}{|l|} 
項目 \\
\end{tabular} & \multicolumn{2}{|c|}{2 点 } & 4 点 & \multicolumn{4}{|c|}{6 点 } \\
\hline 項目 & 1. 2. & & & 3 倍以下 & 5 3 倍上 & 3 & $20 \%$ 增 & 以下 & $30 \%$ 増以下 & \multicolumn{4}{|c|}{$30 \%$ 増以上 } \\
\hline & 4.5 .6$. & \multicolumn{2}{|c|}{3 倍以下 } & $\frac{3 \text { 倍以下 }}{4 \text { 倍以下 }}$ & \multicolumn{2}{|c|}{4 倍以上 } & & & & \\
\hline \multicolumn{2}{|c|}{ H Bs 抗原 } & & & & \multicolumn{2}{|c|}{ ICG (15分値) } & & & & \multicolumn{2}{|c|}{ 肝生検 } & & \\
\hline \multicolumn{2}{|c|}{7} & 正 & 常 & 值 & $5 / 17$ & 1 & I & 1 & 1 & 1 & 1 & 1 & 1 \\
\hline \multicolumn{2}{|c|}{1 総蛋 白 } & & $.0 \sim \varepsilon$ & 8.0 & & & & & & & & & \\
\hline 2 & $\begin{array}{l}\text { 総ビリ } \\
\text { ルビン }\end{array}$ & & $m \sim 2 \sim d$ & & 0.8 & & & & & & & & \\
\hline 3 & $\mathrm{~A} / \mathrm{G}$ & & $1.0 \sim 1$ & & 1.58 & & & & & & & & \\
\hline 4 & $\mathrm{G} O \mathrm{~T}$ & 8 & $3-40 \mathrm{~K}$ & $\mathrm{KU}$ & 65 & & & & & & & & \\
\hline 5 & G P T & & $5-35 \mathrm{~K}$ & $\mathrm{KU}$ & 80 & & & & & & & & \\
\hline 6 & $\gamma-\mathrm{GTP}$ & & $\mathrm{O} \mathrm{n} / m \ell$ & & 60 & & & & & & & & \\
\hline & 力起床時に & 体が & だるい & 3点 & 有·無 & 有·無 & 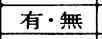 & 有·無 & \begin{tabular}{l|l} 
亚 & 有·無 \\
\end{tabular} & \begin{tabular}{l|} 
有·無 \\
\end{tabular} & 有·無 & $\begin{array}{l}\text { 有·無 } \\
\end{array}$ & 有·無 \\
\hline & 苒中は体が & だる & & 3 点 & 有·無 & 有·無 & 有·無 & \begin{tabular}{|l|} 
有·無 \\
\end{tabular} & 無 & 有·無 & \begin{tabular}{|l|} 
有·無 \\
\end{tabular} & 有·無 & 有·無 \\
\hline & 早中、体少 & だる & & 4 点 & 有·無 & 有·無 & 有·無 & 有・無 & 無 & 有·無 & 有·無 & 有·無 & 有·無 \\
\hline & 後になると & 体が & だるい & 3 点 & 有·無 & \begin{tabular}{|l|} 
有·無 \\
\end{tabular} & 有·無 & 有·無 & \begin{tabular}{l|l} 
黄 & 有·無 \\
\end{tabular} & 有·無 & 有・無 & 有·無 & 有·無 \\
\hline & 支がだるい & & & 3 点 & $\begin{array}{l}\text { 有·無 } \\
\end{array}$ & 有·無 & \begin{tabular}{|l|l|} 
無 \\
\end{tabular} & 有·無 & \begin{tabular}{l|l} 
咞 & 有·無 \\
\end{tabular} & \begin{tabular}{l|l|} 
有·無 \\
\end{tabular} & \begin{tabular}{|l|l|} 
有·無 \\
\end{tabular} & 有·無 & 有·無 \\
\hline & 军が進まな & & & 3 点 & $\begin{array}{l}\text { 有·無 } \\
\end{array}$ & \begin{tabular}{|l|} 
有·無 \\
\end{tabular} & \begin{tabular}{|l|l|} 
無 \\
\end{tabular} & 有·無 & \begin{tabular}{l|l} 
羔 & 有·無 \\
\end{tabular} & \begin{tabular}{|l|} 
有·無 \\
\end{tabular} & \begin{tabular}{|l|} 
有·無 \\
\end{tabular} & $\begin{array}{l}\text { 有·無 } \\
\end{array}$ & $\begin{array}{l}\text { 有·無 } \\
\end{array}$ \\
\hline & 欠がない & & & 3 点 & 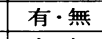 & 有·無 & \begin{tabular}{|l|l|} 
無 \\
\end{tabular} & $\begin{array}{l}\text { 有·無 } \\
\end{array}$ & \begin{tabular}{|l|l} 
無 & 有・無 \\
\end{tabular} & \begin{tabular}{|l|l|} 
有·無 \\
\end{tabular} & 有·無 & $\begin{array}{l}\text { 有·無 } \\
\end{array}$ & $\begin{array}{l}\text { 有·無 } \\
\end{array}$ \\
\hline & F後気持ち & が悪 & & 3 点 & $\begin{array}{l}\text { 有·無 } \\
\end{array}$ & \begin{tabular}{|l|} 
有·無 \\
\end{tabular} & \begin{tabular}{|l|l|} 
無 \\
\end{tabular} & 有·無 & 無 有·無 & 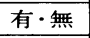 & 有·無 & $\begin{array}{l}\text { 有·無 } \\
\end{array}$ & $\begin{array}{l}\text { 有·無 } \\
\end{array}$ \\
\hline & 夏時に気持 & ちが & 悪い & 3 点 & 有·無 & \begin{tabular}{|l|} 
有·無 \\
\end{tabular} & 有·無 & 有·無 & 無 有·無 & 有·無 & \begin{tabular}{|l|} 
有·無 \\
\end{tabular} & 有·無 & 有・無 \\
\hline & にいものを & $=0$ & のまない & \begin{tabular}{|l|l|}
2 & 3 点 \\
\end{tabular} & 有·無 & \begin{tabular}{|l|} 
有·無 \\
\end{tabular} & 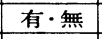 & 有·無 & 簧 有·無 & $\begin{array}{l}\text { 有·無 } \\
\end{array}$ & \begin{tabular}{|l|l|} 
有·無 \\
\end{tabular} & 有·無 & 有·無 \\
\hline & 角がこる & & & 3 点 & $\begin{array}{l}\text { 有·無 } \\
\end{array}$ & \begin{tabular}{|l|} 
有·無 \\
\end{tabular} & \begin{tabular}{l|} 
有·無 \\
\end{tabular} & $\begin{array}{l}\text { 有·無 } \\
\end{array}$ & 無 有·無 & 有·無 & 有·無 & $\begin{array}{l}\text { 有·無 } \\
\end{array}$ & 有·無 \\
\hline & 中に痛や重 & さを! & 感じる & 3 点 & 有·無 & \begin{tabular}{|l|} 
有·無 \\
\end{tabular} & 有·無 & 有·無 & \begin{tabular}{l|l} 
El & 有·無 \\
\end{tabular} & $\begin{array}{l}\text { 有·無 } \\
\end{array}$ & 有·無 & 有·無 & $\begin{array}{l}\text { 有・無 } \\
\end{array}$ \\
\hline & 角や頭重が & ある & & 3 点 & 有·無 & \begin{tabular}{|l|} 
有·無 \\
\end{tabular} & 有·無 & \begin{tabular}{|l|} 
有·無 \\
\end{tabular} & \begin{tabular}{l|l} 
簧 & 有·無 \\
\end{tabular} & 有·無 & 有·無 & 有·無 & 有・無 \\
\hline & 伎がつる & & & 3 点 & 有·無 & 有·無 & \begin{tabular}{|l|l|} 
無 \\
\end{tabular} & $\begin{array}{l}\text { 有·無 } \\
\end{array}$ & \begin{tabular}{l|l} 
镸 & 有·無 \\
\end{tabular} & \begin{tabular}{|l|l|} 
有·無 \\
\end{tabular} & \begin{tabular}{|l|} 
有·無 \\
\end{tabular} & $\begin{array}{l}\text { 有·無 } \\
\end{array}$ & $\begin{array}{l}\text { 有·無 } \\
\end{array}$ \\
\hline & 李肋部に異 & 状を! & 感じる & 4 点 & 有·無 & \begin{tabular}{|l|} 
有·無 \\
\end{tabular} & \begin{tabular}{|l|l|} 
無 \\
\end{tabular} & 有·無 & \begin{tabular}{l|l} 
饾 & 有·無 \\
\end{tabular} & 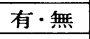 & \begin{tabular}{|l|l|l} 
無 \\
\end{tabular} & $\begin{array}{l}\text { 有·無 } \\
\end{array}$ & $\begin{array}{l}\text { 有·無 } \\
\end{array}$ \\
\hline & ライラする & & & 3 点 & 有·無 & \begin{tabular}{|l|} 
有·無 \\
\end{tabular} & \begin{tabular}{|l|l|} 
無 \\
\end{tabular} & $\begin{array}{l}\text { 有·無 } \\
\end{array}$ & \begin{tabular}{l|l} 
無 & 有·無 \\
\end{tabular} & 有·無 & \begin{tabular}{|l|l|l|l} 
無 \\
\end{tabular} & $\begin{array}{l}\text { 有·無 } \\
\end{array}$ & $\begin{array}{l}\text { 有·無 } \\
\end{array}$ \\
\hline & 安感がある & & & 3 点 & 有·無 & \begin{tabular}{|l|} 
有·無 \\
\end{tabular} & 有·無 & 有·無 & \begin{tabular}{l|l} 
算 & 有·無 \\
\end{tabular} & 有·無 & 有·無 & $\begin{array}{l}\text { 有·無 } \\
\end{array}$ & 有・無 \\
\hline & こ、かゆみ & があ & & 3 点 & 有·無 & \begin{tabular}{|l|} 
有·無 \\
\end{tabular} & 有·無 & 有·無 & \begin{tabular}{l|l} 
茾 & 有·無 \\
\end{tabular} & 有·無 & \begin{tabular}{|l|l|} 
無 \\
\end{tabular} & 有·無 & 有·無 \\
\hline & 2むりが浅 & & & 3 点 & $\begin{array}{l}\text { 有·無 } \\
\end{array}$ & \begin{tabular}{|l|} 
有·無 \\
\end{tabular} & \begin{tabular}{|l|l|} 
無 \\
\end{tabular} & $\begin{array}{l}\text { 有·無 } \\
\end{array}$ & $\begin{array}{l}\text { 有·無 } \\
\end{array}$ & 有·無 & \begin{tabular}{|l|l|} 
有·無 \\
\end{tabular} & & $\begin{array}{l}\text { 有·無 } \\
\end{array}$ \\
\hline & 中々ねつか & れな & $\omega$ & 3 点 & $\begin{array}{l}\text { 有·無 } \\
\end{array}$ & \begin{tabular}{|l|} 
有·無 \\
\end{tabular} & $\begin{array}{l}\text { 有·無 } \\
\end{array}$ & 有·無 & \begin{tabular}{l|l} 
塂 有·無 \\
\end{tabular} & $\begin{array}{l}\text { 有·無 } \\
\end{array}$ & \begin{tabular}{|l|l|} 
有·無 \\
\end{tabular} & 有·無 & 有·無 \\
\hline & 合 & & 計 & & 点 & 点 & 点 & 点 & 点 & 点 & 点 & 点 & 点 \\
\hline & & 4 & ' & ' & ' & ' & ' & ' & ' & ' & ' & ' & ' \\
\hline & 治 & 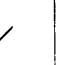 & / & ' & / & I & ' & ' & ' & ' & ' & ' & ' \\
\hline & 年 & $\zeta$ & ' & ' & I & ' & ' & / & ' & / & I & I & I \\
\hline & 月 & $\zeta$ & ' & ' & ' & ' & ' & ' & ' & ' & ' & ' & ' \\
\hline & 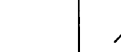 & I & ' & ' & ' & / & ' & / & I & I & I & I & / \\
\hline
\end{tabular}




\section{I -3 腰痛症}

山田 勝弘

銊炎師にとって腰痛は非常に治療機会の多い疾患で あり，また腰痛は鍼炎の最適応症ということになって いる。従って銊炎師は, 腰痛についての診察および治 療に必要な知識を学び理解を深めることは, 日常の治 療を行う上でぜひ心がけねばならないことであろう。

本学会のワークショップは「針治療の客観的効果判 定のための統一カルテの使い方の実際」ということが 目的であるが，このカルテでは，腰痛に対する針炎治 療のための診察のうち, 検査法（視診・触診・運動負 荷テスト・理学テス卜等）を行い, その内容からその 病態を把握し, 腰痛を起している疾患を鑑別するため の，チャート作製に重点を置いてみた。

たとえ単純な腰痛でも, 腰部の椎骨および軟部組織 が原因となるのみでなく, その他, 内臓の関連痛・腫 瘍・感染症・炎症性疾患などによっても生じることが あり，腰痛を治療する際にもこれらのことを充分心得 ておく必要がある。

このような見地から，カルテの 1 ページ目は，患者 の全体像をとらえ, 腰痛が腰部のみでなく，他の原因 に基づいたものではないかをチエックすることを目的 としたものである。これらの項目のうち，家族歴とか 嗜好，体質傾向などは腰痛治療には直接関係がないよ うに思われるのだが，患者全体の養生という立場に立 つと大切な項目になってくるし，体質的傾向は，刺針 の際の刺激量を決めるのに大変重要であると考えてい る。

2 ページ目は腰痛の診察および鑑別のためのチャー トである。

先にも述べたように，腰痛には種々の原因があり， またさまざまな症状が考えられる。従ってこれらの原 因や症状を分析し，その結果から腰痛の病態を分類(鑑 別）する必要があると考えられ，これは腰痛を効率良 く治療するうえでも重要なことである。

このカルテの診察項目は西洋医学的な見地からのも のである。これは先にも述べたのであるが, 腰痛が持 つ全身的な背景および病態の複雑さを考えた時に，西 洋医学の方が，より良い分析をしていると考えたため である。

診察項目は(1)視診・触診(2)運動負荷時痛(3)理学テス トに分かれている。腰痛を訴える患者になるべく負担
にならないようにそれぞれの体位において出来得る各 検査項目を調べるようにして患者に何度も同じ体位を くり返えさせないように配慮すべきであろう。

また，これらの診察項目の「判定基準」が問題にな るところであるが，これは患者の個人差などの問題も 含み厳密に統一出来得ない点もあるのだが，健康体を も含めてより多くの症例を観察し, これらの診察項目 に慣れることである。また，これらの一つ一つの項目 がどのような意味を持つものか良く理解すれば，何故 この検査を行う意義があるのかという目的がわかるよ うになる。初心者や，まだ理解が充分でない人は，こ こに取り上げてある診察項目について立分経験してい る人に説明してもらうことも良いと思われる。

次は, 診察によって得られた結果に基づいて鑑別診 断を行なう。腰痛をもたらす疾患はここにとり上げた もの以外にも存在するかと思われるが，われわれ鍼炎 師が遭遇する機会が多いと考えられるものを取り上げ たのである。

腰痛に対する銊炎治療を考之る場合に，その原因ま たは病態を考えずして，いわゆる対症的な治療に終始 することは効率良い治療にならないと考える。腰痛を 検查し，その原因病態を推察することは，その背景と なる重大疾患を見落さないためにも，また治療方法の 決定さらに治療効果判定を行なう際にも重要なことだ と考える。

鑑別された疾患についての治療法は当然それぞれ に原因および病態が異なるのでそれに対応した方法が あると思われるが，今回はこのカルテの目的と異なる ので別の機会に譲ることにする。

また，今回のカルテ作製の目的の一つとされていた 効果判定については全く触れていないのであるが, こ のカルテでは検査および病態把握の方に重きを置いた のでこのようなカルテになった次第である。この点に 関しては次回の神戸大会までに，本来のカルテの目的 に沿ったものに改訂したいと考えている。

（テ158 東京都世田谷区用賀4-12-6

$$
\text { ソアラ日康マンション102号) }
$$


全日本鋮负学会腰痛カルテ

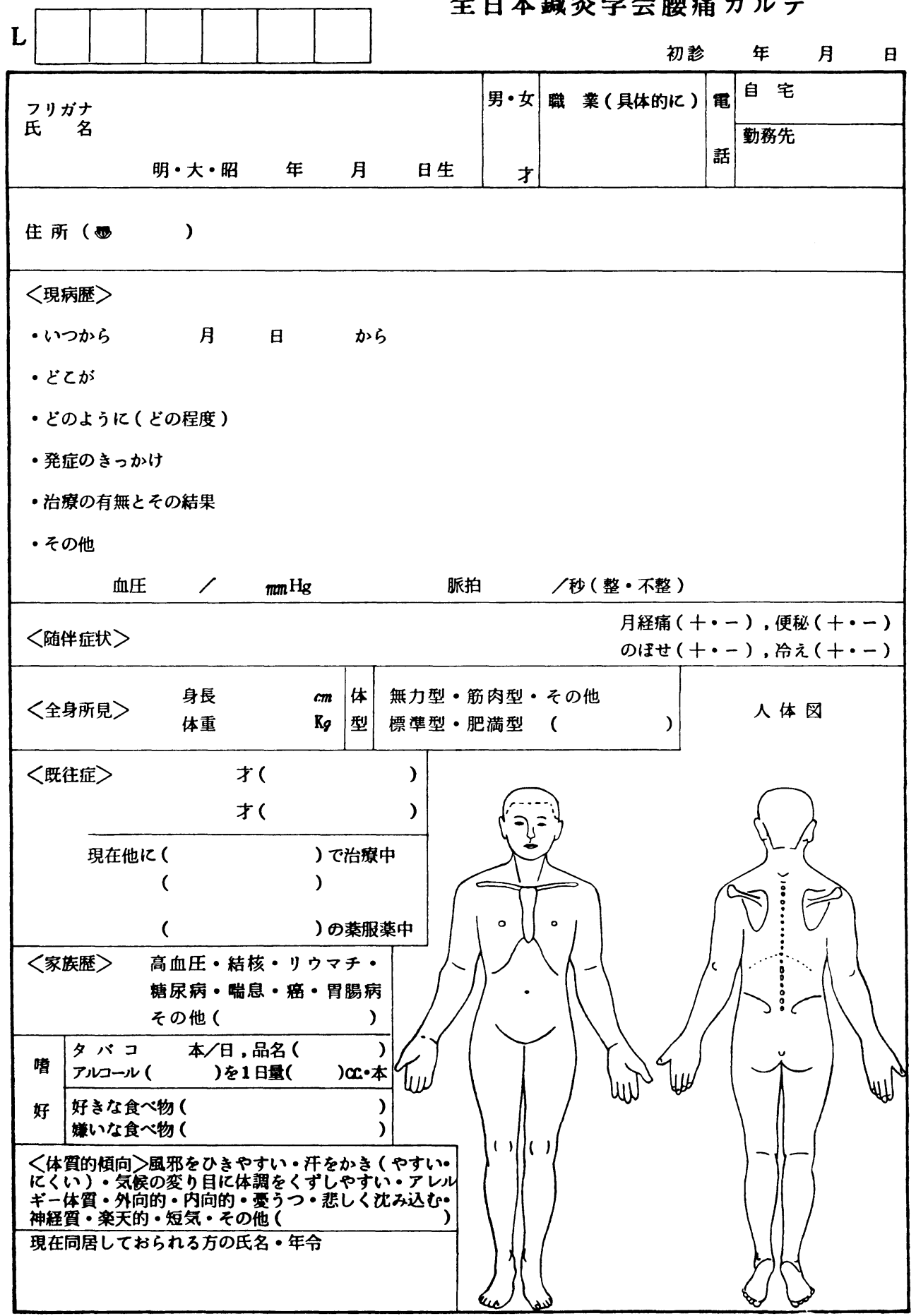


腰痛カルテ裏面

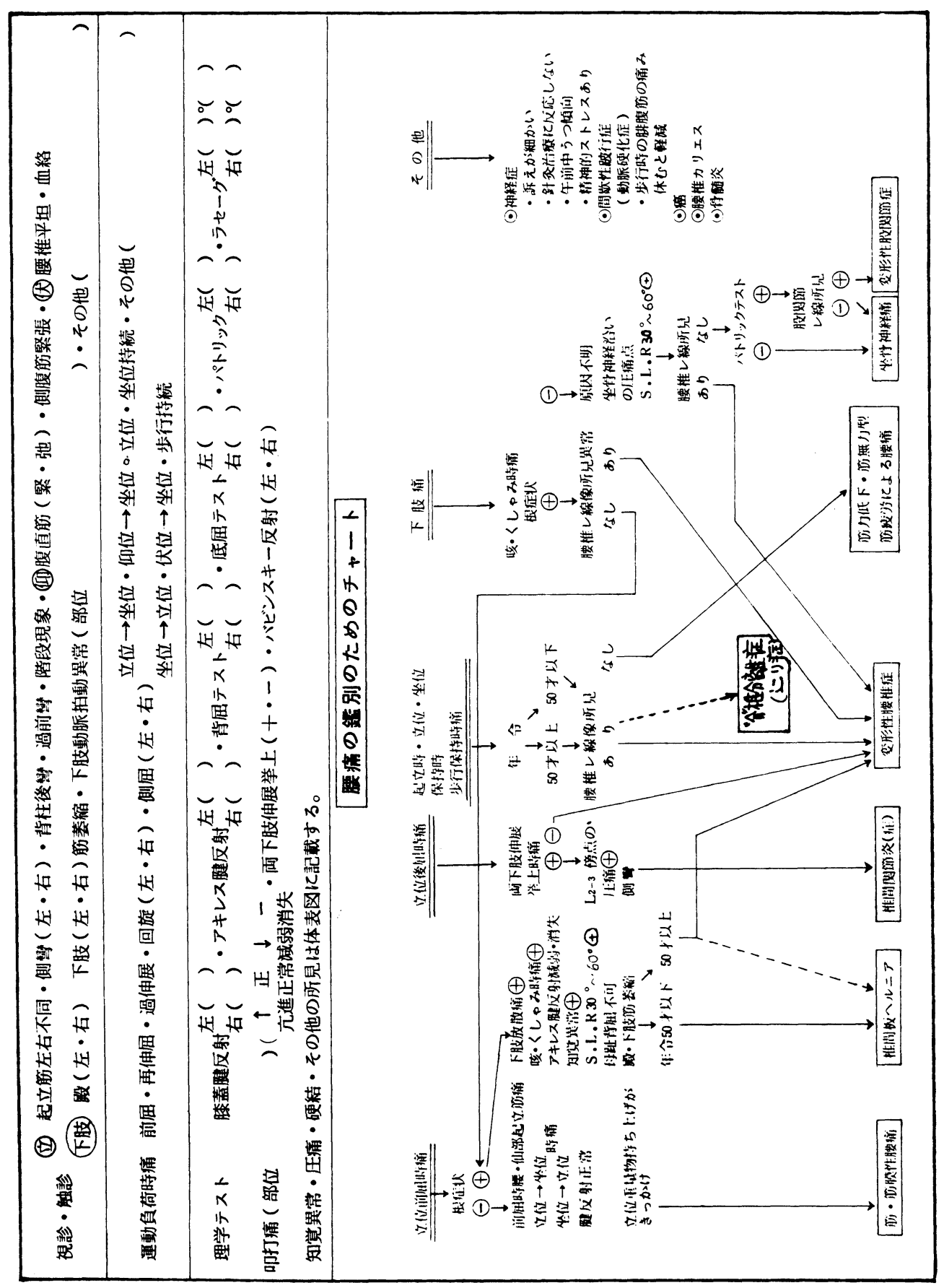




\section{I -4 膝痛カルテを用いた診療の進め方

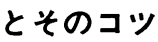

（）北出 利勝 ○篠原 昭二 (ㅇ)班長 ○副班長

銊尒の治療効果を客観的に評価するためには，十分 な診察技術を必要とすることはいうまでもないことで ある。しかし，レントゲンや血液検查その他現代医学 的な検查手段を持たずに，ただ徒手検査のみで診察を すすめるには，おのずと限界があり，また相当な技術 と経験が必要であると思われる。もちろん，病院内あ るいは近医との綿密なチームプレーのできるシステム を持っていれば話は別である。

しかし，ほとんどの開業鍼炎院においては，なかな かこういった連携が十分に機能していないと思われる。

また，診察手技の1つとしての徒手検査についてみ ても，系統だった専門学校教育の課程の中に取り入れ られてきたのも最近のことであり，ほとんどの場合が 研究会や独学で研讃を積んでいるのが現状であろう。

膝痛班において，不十分ながら膝痛に対する鍼炎治 療効果の客観的判定を意図して, 第 1 回の専用カルテ を試作するにあたって,「日本針尒皮電学会製の滕の痛 みカルテがあるのにそれを使えば十分すぎる位ではな いか」というのがいつわらざる考之であった。しかし， 現実にそのカルテの使用状況を調べてみると専門学校 ですら十分にとり入れられていないのが現状のようで あった。

そこで,「誰でも，簡単に，すぐ実施できるカルテを」 と，主観的評価（自覚的症状）を主として作成したの である。このカルテに対するアンケートならびに質疑 の中では，治療方法や刺激量に関する質問と「もっと 詳細で厳密な検查を」という意見も少数ながら指摘が あった。

今回，対象疾患を“変形性膝関節症”に絞って，本 症に対する専用カルテの作成を行い，短時間でしかも 限られた検查法によって，ある程度本症を予測しよう としたものである。また，患者記載用のアンケート用 紙も作成し， 1 回治療当りの効果とその持続時間（直 接効果)についても検討しようと試みた。もちろん， これだけの内容で他疾患と鑑別し，疾患を断定しうる ものではない。本症を疑われるような症状に対して， 鍼炎治療効果の記録が主観的，客観的を問わず， 1 例 でも多く集まれば，何かの答えが導びき出せるであ
ろう。

以下，ベッドサイドでの問診から，カルテにそって 診察のす寸め方とそのコツについて述べる。

\section{ロベッドサイドでの問診}

膝痛カルテ（図１）の表面の記載は従来のカルテと 同様であるが, 年齢, 身長・体重・標準体重, 既往年 月日, 職業などからも变形性膝関節症の疑いがもてる であろう。例之ば，年齢が 40 代以上で，肥満度* が30 $\% ， 2$ 年くらい前から徐々に膝の痛みを訴之，農業を やっているなどである。

現病歴では, 膝痛に至る原因（外傷や急激な運動で は, 半月板損傷, 側副靶帯・十字靶帯損傷などが疑わ れ，このときにはマクマレーテスト，アプレーテスト を行って陽性であれば，変形性膝関節症から外すべき であろう), 症状の経過（仕事をすると悪化するなど）, 痛みの状態などを細かく問診する。

現症では，今回はあまりとりあげていないが，脈診、 腹診, 切経などを行って, 経絡異常の有無を観察する ことも有意義なことであり今後の興味深い問題である。

\section{$\square$ 鍼负治療について}

治療に関しては, 第 1 回のカルテの内容とあまり変 わらないが，痛みの部位を(1)軟部組織型（腓腹筋，黛 足部分, 側副靸带, 大腿四頭筋など軟部組織に問題が あって痛みを訴えるケース),(2)骨・関節型（軋音があ り，起坐動作特にしゃがんだ状態から立てるとき，階 段昇降時の痛みなどを訴之るケース), (3)混合型（1), (2)の両方を訴えるケース) に分類し，軟部組織型の治 療は軟部組織への刺鍼を主として行い，骨・関節型に ついては関節内刺銊をよく消毒の上で施行するのも効 果的であると考えている。

\section{$\square$ 治療効果の判定法}

次に，カルテ襄面（図 2 ）の判定法について順をお って簡単に説明する。

判定の表は，来院時治療前にそれぞれの項目につい て質問し，あるいは他覚的に検査し， $0 ， 1 ， 2 ， 3$ あるいは十，士，一などその時の状態を把握し，左右 別々に空欄に記入していく。(○)または $(-)$ 以外の項 目については, 治療直後に再度検査し, その結果を術 後の闌に記入する。1から10の番号の下には測定日を

*肥満度 $=(1-$ 標準体重 $\div$ 体重 $) \times 100(\%)$

標準体重 $=($ 身長 -100$) \times 0.9$

たとえば身長 $160 \mathrm{~cm} の 人 の$ 標準体重は $54 \mathrm{~kg}$,

肥満度10\%は60kg, 20\%は67.5kg, 30\%は77.1 kg 


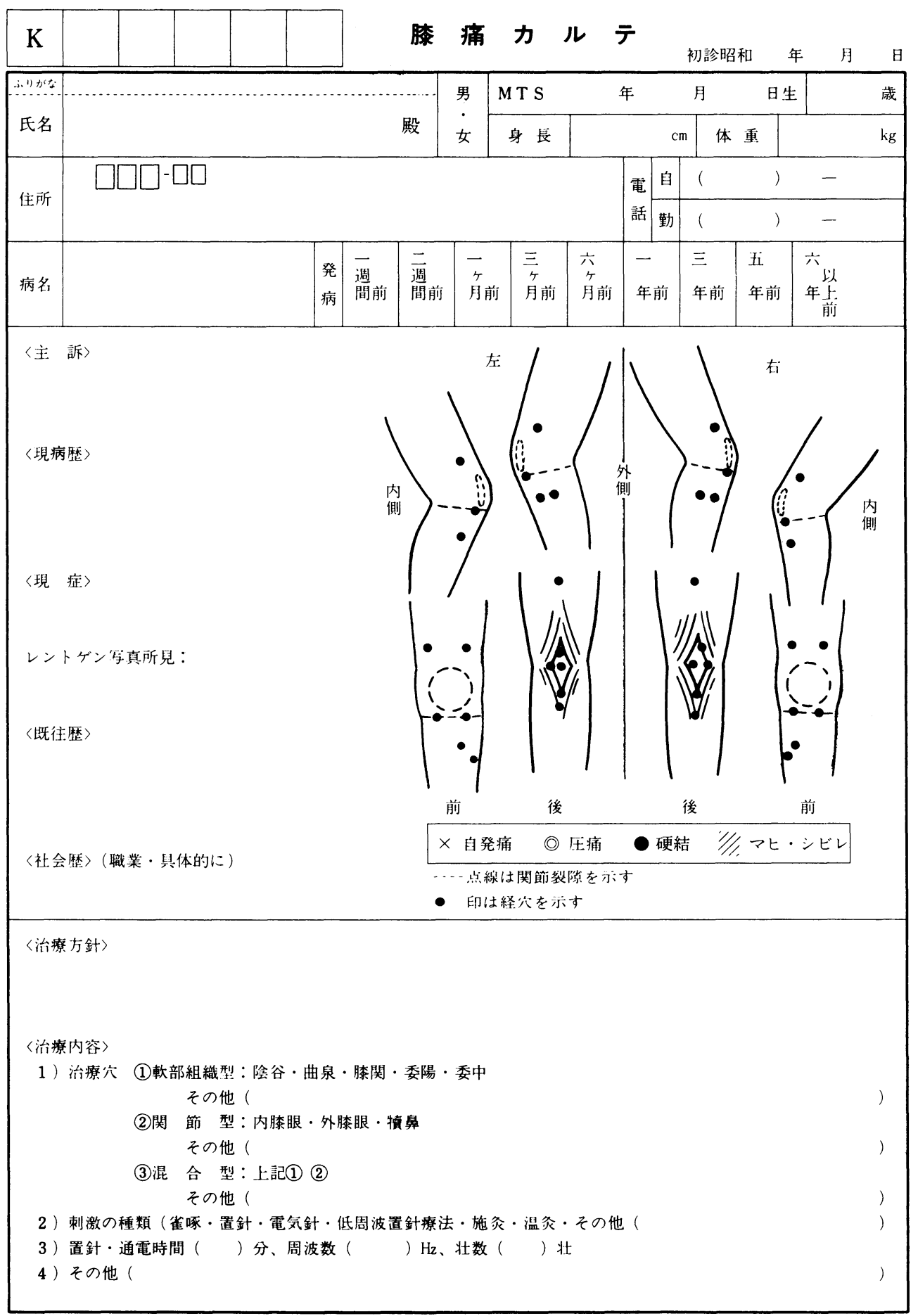

図 1 膝痛カルテ(改訂) 


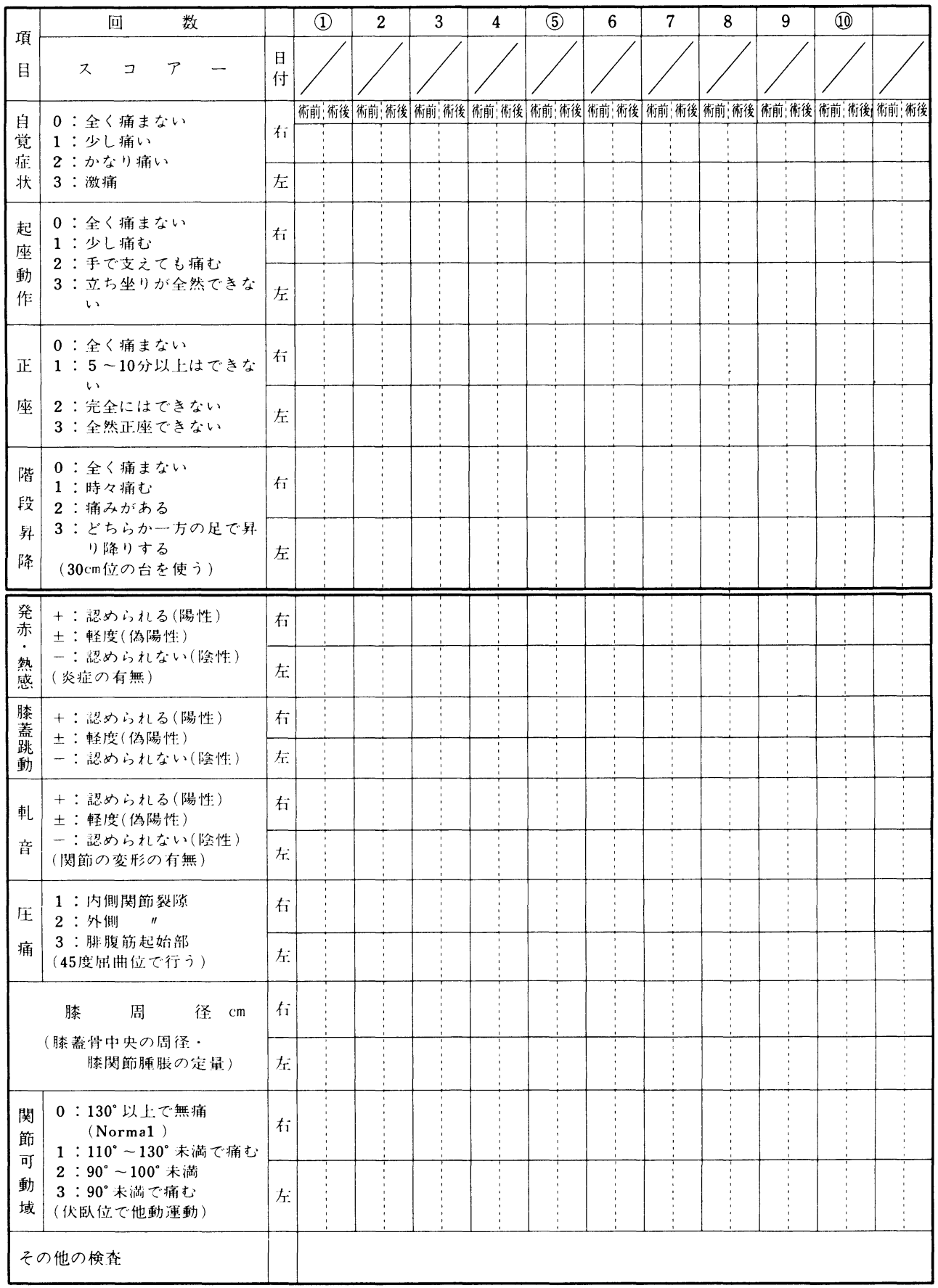


記入する。

(1)自覚症状

これは, 日常生活に扔ける不自由度について, 患者 の主観的な訴えを，0から 3 までの 4 段階に分けて左 あるいは右の欄に番号で記入する。ここでもしVAS 判定を行っている場合 (現在の苦痛の程度が $0 \sim 10$ の 間でどれくらいかを指摘させる) には，その数值を記 入してもさしつかえない。

(2)起坐動作

立った状態から座るとき，座った状態から立つとき に苦痛があるかどうかを確認し，そのときの主観的な 訴之を空欄に番号で記入する。起坐動作に異常がない ときは、しゃがんだ状態から立つときに痛みがあるかど うかも参考になる。通常この場合に, 滕蓋骨と大腿骨の 関節面には体重の7.6倍の負荷がかかるとされている。 (3).正 坐

正坐をさせ，その時の状態を観察して空欄に番号で 記入する。正坐をしょうとして膝の前面(膝蓋骨の上) に痛みがあれば，大腿四頭筋，内側は，黛足を構成す る筋群, 後面は腓腹筋の緊張による痛みを訴之る場合 が非常に多い。

(4)階段昇降

階段を昇りおりさせた時の状態をみる。階段がない 場合には, 高さ $30 \mathrm{~cm}$ 位の台を用いて観察する。

このとき，どちらの足が苦痛で，どちらの足で昇ろう (降りよう)とするか。またこの時最も苦痛とするのは 昇る時か降りる時か, それとも両方とも同様に苦痛で あるかなどを備考欄に記入しておく。この場合に, 滕 がガクンと折れるような, あるいは力が入らずに不安 定感を訴えるケースでは，大腿四頭筋の筋力低下ある いは萎縮している場合があるので, 治療には運動療法 による筋力増強も考慮すべきであろう。

(5)発赤・熱感

左右の膝関節を比較し, あるいは触って 発赤や熱感があるかどうかを観察し，認め られれば $(+)$, 正常であれば(一)，どちら か不明な場合，あるいはどちらともいえな い場合は(土)の記号を空欄に記入する。発 赤・熱感は炎症症状の一つであり, 症状が きつければ銊の深刺や関節内刺鍼は見あわ せ，まず整形外科の受診をすすめるべきで あると考える。また慢性関節りウマチとの 鑑別も必要であろう。

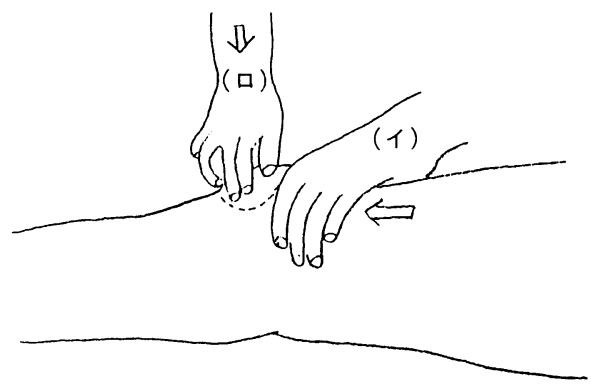

図3

\section{(6)滕蓋跳動}

仰臥位で(イ)一方の手を滕蓋骨の上 $15 \mathrm{~cm}$ 位より䍒蓋 骨上縁まですべらせ，しぼるようにして膝蓋骨上のう 部の浸出液を押し出し, (口)他方の手の母指と他の 3 指 の指尖を膝蓋骨の真上に置き，すばやく下方に圧す。 数回やってこの時コツコツと音があれば浸出液の存在 を示し, 空欄に $(+)$ を書く。認められない場合は $(-)$, 軽度であれば $( \pm)$ とする。この時, 膝蓋骨の可動性や, なめらかに動くかどうかもみておくとよい。外傷ある いは，受傷後速やかに膝関節部の腫脹と疼痛を来す場 合には，血腫の場合が多く，整形外科的処置の必置な ケースが多い。水腫の場合には通常12 24時間で出現 するとされている。さらに, このとき膝蓋骨を圧迫し ながら, 上下, 左右に他動的に動かせて, 軋音, 運動 性制限, 疼痛の有無（膝蓋骨圧迫テスト）をみてお くと,大腿骨と滕蓋骨の関節症を知ることができる(図 $3)$ 。

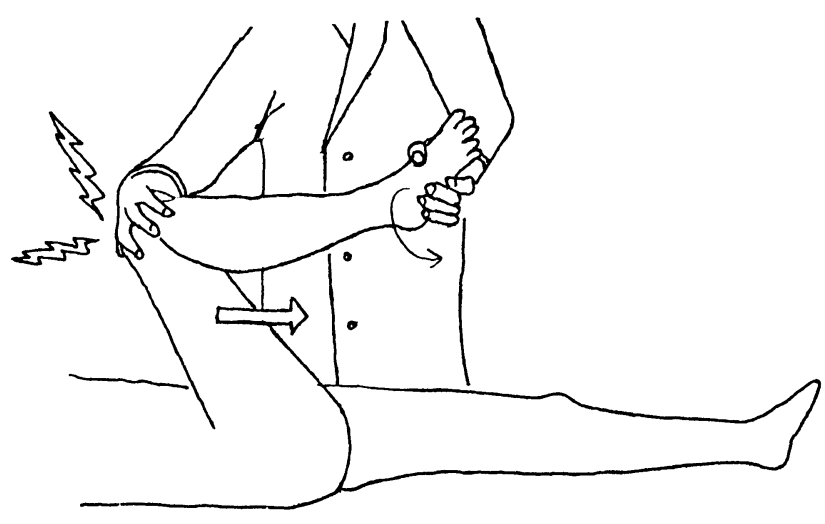

図4 
(7)軋 音

仰臥位で股・膝関節を最大限に屈曲させ，一方の手 で患者の踵をもち，他方の手を膝関節（膝蓋骨の上） にあてゆっくり股・膝関節を伸展する。このとき, 痛 みや膝関節においた手に軋音を感じるかどうか観察す る。足関節の内旋, 外旋を加えればマクマレーテスト として, 半月板損傷のテストとして用いられる。ポキ ッ，ゴキッという音は半月板損傷による場合が多く， 変形性膝関節症においては, 異様な摩擦感, こすれあ うような感じをうけることが多い（図４）。

\section{(8)圧 痛}

仰臥位で股・膝関節を約 45 度屈曲した状態で, 前方 より内側・外側関節裂隙部の圧痛点をみる。さらに前 方より膝窩の方に手を回し，腓腹筋起始部の圧痛を観 察し，圧痛があれば $1 ， 2 ， 3$ ，の該当する番号を空 欄に記入する。変形性膝関節症によって骨棘が形成さ れると関節裂隙部に圧痛を認めることが多いが, 側副 靸帯, 半月板損傷でも圧痛をみる場合があり注意を要 する。

(9)滕周径

仰臥位で膝を伸展した状態で膝蓋骨中央又は，膝蓋 骨の上縁の上約 $2 \mathrm{~cm}$ 位の周囲をメジャーで実測する。 滕蓋骨上縁の上 $10 \mathrm{~cm}$ 位の周径を計っておけば, 大腿四 頭筋萎縮（内側広筋が最も筋力が大きい）を知ること ができよう。

(10)関節可動域

患者を腹臥位とし, 膝伸展位 $0^{\circ}$ とる。そして図の ように角度計をあて, 患者の自動的膝屈曲の最大值の 角度にあてはまる番号を記入する。この時, 患者が痛 みを感じた最初の屈曲角度を運動角度とする（角度計 を指定する)。

この時に, 膝関節を最大に屈曲させて, 大腿前面一 外側, ならびに繁部がもち上がれば，大腿直筋の短縮 があることを知ることができる。この場合には，大腿 前面部への雀啄刺激も有効であろう（図 5 )。

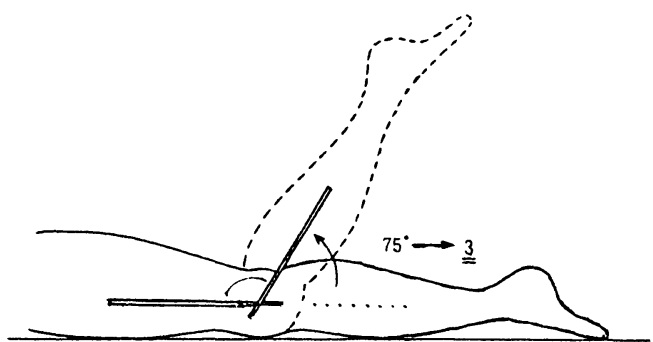

図5

\section{アンケート用紙の使用法}

次にアンケート用紙（図6）の使用方法についてで あるが, これは 1 回治療後の鍼治療効果が何日くらい 持続するかという直接効果を調べるものである。銊治 療は 1 回で, ある程度の軽減を自覚させないとあまり 長続きしないのが現実であり，そのためにも 1 回治療 の効果というものを具体的に知っておく必要がある。

判定は, まず痛みを全く感じない(0)から, 現在ある 苦痛の程度(10)までの11段階に分類する。その後, 治療 した当日の夕方でも昼でも任意の時間（最も気になる 時間带に統一するのがよい）の痛みの程度を，前記 0 〜10段階のいずれに変化したか（何割残っているか） を書いてもらうのである。その後は 2 日目，3 日目， 4 日目と書いても.らい, 最後の欄には, 治療前の苦痛 と同程度にもどった日数を書いてもらうのである。

例之ば, 治療当日が 3 割, 2 日目が 6 割, 3 日目が 8割であるとすれば，それぞれ，(3)，(6)，8の欄に○ 印をつければよい。さらに 5 日目には元にもどったと すれば最後の闌には(5)を書けばよいことになる。

もし，老人患者等で十分書き方が理解できていない と判断される場合には，術者の方で詳細を聞いて書き こんでもらえばよいわけである。

\section{むすび}

以上，変形性膝関節症を主とした膝痛患者に対する 膝痛カルテとアンケート用紙の使い方について，私見 をまじえて解説した。先の福井での学会においておこ なわれたワークショップのアンケート調查の結果,「カ ルテの記載方法」については，94\%が一部を除いてほ ぼ理解できるとしているが,「これからこのカルテを使 いたいと思うか」に対しては，使うがわずか $14 \%$, 使 わないが $29 \%$ ，少し改良して使いたいが56\%であった。 （滕痛カルテの記載例を図 7, 図8にかかげた)一口に 膝痛といっても変形性膝関節症だけとは限らず, 診断 は決して容易ではなく, ましてや多忙な臨床の合間を 縫ってでのカルテ記載であり, 大変な労力であると推 察する。しかし，たとえ1例でも，また「こういう病 態には効かなかった」というネガティブケースでもい ただければ，それは貴重なデータとして使いうると考 える。全国の開業されている鍼炎師あるいは，病医院 勤務を問わず，身近にある貴重な 1 例が，鍼炎の真の 治療効果を世に問いうる1歩となるであろう。

本稿は, 昭和57年 6 月 4 日, 全日本銊炎学会・福井 市文化会館, ワークショップでの報告である。

( T629-03 京都府船井郡日吉町 明治銊尒大学) 
アンケート用紙

\begin{tabular}{|c|c|}
\hline & 治 療 日 \\
\hline 1 回目の鏚 & \multicolumn{1}{|c|}{} \\
\hline 2 回目の銊 & \\
\hline
\end{tabular}
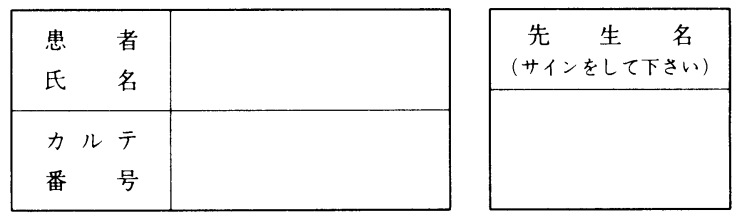

本日、治療いたしましたが、その効果をありのままに

下記に○印をご記入下さい。

【治療前の苦痛を「10」としてお答え下さい

\begin{tabular}{|c|c|c|c|c|c|c|c|}
\hline 苦痛の度 合 & 治療前の苦痛 & \multirow{12}{*}{ 治 } & 治撩当日の効果 & 2 日目 & 3 日目 & 4 日目 & 日目 \\
\hline & 0 & & & & & & O \\
\hline & & & & & & & \\
\hline & & & & & & & \\
\hline & & & & & & & \\
\hline & & & & & & & \\
\hline & & & & & & & \\
\hline & & & & & & & \\
\hline & & & & & & & \\
\hline & & & & & & & \\
\hline & & & & & & & \\
\hline 苦痛を感じない & & & & & & & \\
\hline
\end{tabular}

※ 治療中および治療後のご感想をお書き下さい。 (なんでもけっこうです)。 


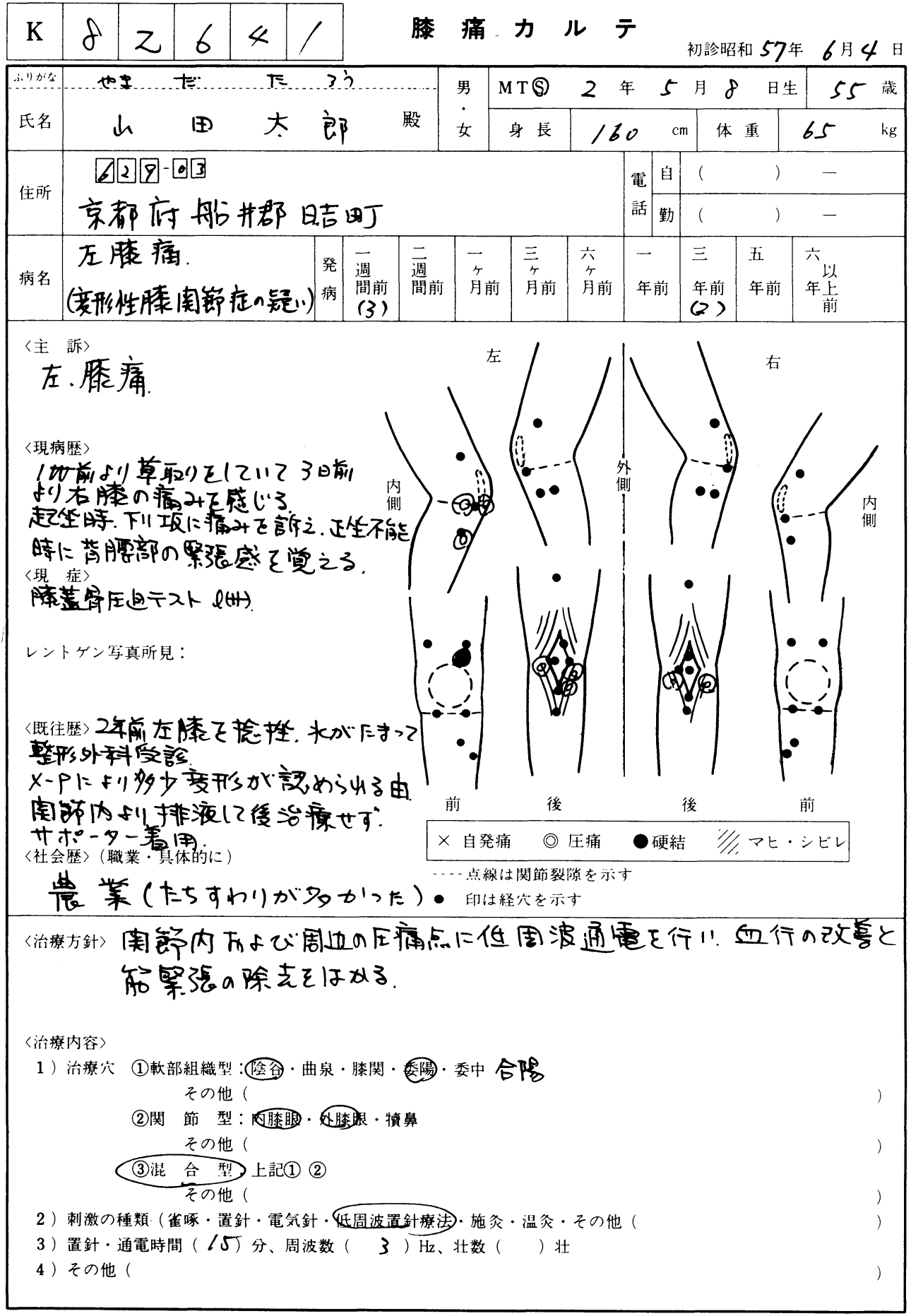




\begin{tabular}{|c|c|c|c|c|c|c|c|c|c|c|c|c|c|}
\hline \multirow{2}{*}{$\begin{array}{l}\text { 項 } \\
\text { 目 }\end{array}$} & 回 & & (1) & 2 & 3 & 4 & (5) & 6 & 7 & 8 & 9 & (10) & \\
\hline & ス $\sqsupset p-$ & \begin{tabular}{|l|} 
早 \\
付
\end{tabular} & & & & & & & & & & & \\
\hline 自 & \multirow{3}{*}{$\begin{array}{l}0: \text { 全く痛まない } \\
1: \text { 少し痛い } \\
2: \text { かなり痛い } \\
3 \text { ：激痛 }\end{array}$} & & 術前; 術得 & 術前；術後 & 術前; ‘術後 & 術前：術後 & 術前; 術後 & 術前; “術後 & 術前；訹後 & 術前; 術後 & 術前，術後 & 術前: 術後 & 術前; 㭪後 \\
\hline $\begin{array}{l}\text { 賞 } \\
\text { 症 }\end{array}$ & & 右 & 0 & & & & & & & & & & \\
\hline 状 & & 左 & 0 & & & & & & & & & & \\
\hline \multirow{2}{*}{$\begin{array}{l}\text { 起 } \\
\text { 侳 } \\
\text { 動 } \\
\text { 作 }\end{array}$} & \multirow{2}{*}{$\mid \begin{aligned} 0 & : \text { 全く痛まない } \\
1 & : \text { 少し痛む } \\
2 & : \text { 手で支えても痛む } \\
3 & : \text { 立ち坐りが全然できな } \\
& \text { い }\end{aligned}$} & 右 & 0 & & & & & & & & & & \\
\hline & & 左 & 21 & & & & & & & & & & \\
\hline \multirow{2}{*}{$\begin{array}{l}\text { 正 } \\
\text { 座 }\end{array}$} & \multirow{2}{*}{ 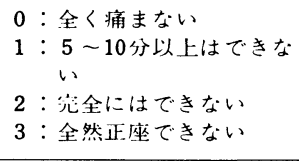 } & 右 & 0 & & & & & & & & & & \\
\hline & & 左 & 21 & & & & & & & & & & \\
\hline \multirow{2}{*}{$\begin{array}{l}\text { 階 } \\
\text { 段 } \\
\text { 年 } \\
\text { 降 }\end{array}$} & \multirow{2}{*}{$\begin{aligned} & 0: \text { 全く痛まない } \\
& 1: \text { 時々桷む } \\
& 2: \text { 痛みがある } \\
& 3: \text { どちらか一方の足で年 } \\
& \text { り)降りする } \\
&(30 \mathrm{~cm} \text { 位の台を使う })\end{aligned}$} & 右 & 0 & & & & & & & & & & \\
\hline & & 左 & 22 & & & & & & & & & & \\
\hline \multirow{2}{*}{$\begin{array}{l}\text { 発 } \\
\text { 赤 } \\
\text { 熱 } \\
\text { 感 }\end{array}$} & \multirow{2}{*}{ 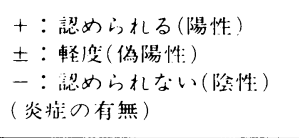 } & 右 & - & & & & & & & & & & \\
\hline & & 左 & ++ & & & & & & & & & & \\
\hline \multirow{2}{*}{$\begin{array}{l}\text { 槂 } \\
\text { 盖 } \\
\text { 動 } \\
\end{array}$} & \multirow{2}{*}{$\begin{array}{l}+: \text { 涊められる(陽性) } \\
\pm: \text { 軽度(偽陽性) } \\
-: \text { 認められない(陰性) }\end{array}$} & 右 & - & & & & & & & & & & \\
\hline & & t: & $+t$ & & & & & & & & & & \\
\hline \multirow{2}{*}{$\begin{array}{l}\text { 䡉 } \\
\text { 音 }\end{array}$} & \multirow{2}{*}{$\begin{array}{l}+: \text { 認められる(陽性) } \\
\pm: \text { 双度(偽陽性) } \\
\text { - : 認められない(㓌性) } \\
\text { (関節の変形の有無) }\end{array}$} & 右 & \pm \pm & & & & & & & & & & \\
\hline & & 左 & $+t$ & & & & & & & & & & \\
\hline \multirow{2}{*}{$\begin{array}{l}\text { 圧 } \\
\text { 痛 }\end{array}$} & \multirow{2}{*}{ 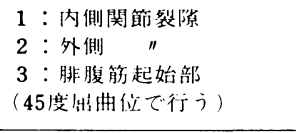 } & 右 & $3-$ & & & & & & & & & & \\
\hline & & 左: & $\begin{array}{l:l}1 & 1 \\
3 & 1\end{array}$ & & & & & & & & & & \\
\hline \multirow{2}{*}{\multicolumn{2}{|c|}{ 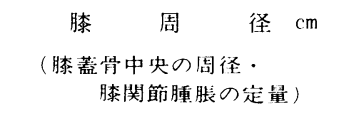 }} & 右 & 30 & & & & & & & & & & \\
\hline & & 左 & 33 & & & & & & & & & & \\
\hline \multirow{2}{*}{$\begin{array}{l}\text { 関 } \\
\text { 節 } \\
\text { 可 } \\
\text { 動 } \\
\text { 域 }\end{array}$} & \multirow{2}{*}{ 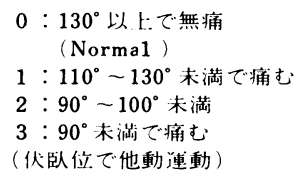 } & 有 & 0 & & & & & & & & & & \\
\hline & & 左: & 11 & & & & & & & & & & \\
\hline \multicolumn{2}{|c|}{ その他の検查 } & $\mathbf{I}$ & 渎 & & & 1 & & & & 7 & - & 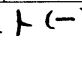 & \\
\hline
\end{tabular}

図8 膝痛カルテの記載例(裏) 


\section{II-1 経穴と非経穴との違い・現れ方}

\section{池田 太喜男}

(1)経穴と非経穴との違い・現れ方

\begin{tabular}{|c|c|c|}
\hline & 穴 & 穴（圧痛点） \\
\hline $\begin{array}{l}\text { 目でみる } \\
\text { (色) }\end{array}$ & $\begin{array}{l}\text { 赤味青味白味。 } \\
\text { 古典では紋文中, 横紋の頭, 赤白肉の際, 爪 } \\
\text { 甲角を去る菲葉の如き青脉の中。 }\end{array}$ & 赤味多い。不明瞭，どこにでも反応出る。 \\
\hline 触診 & $\begin{array}{l}\text { 表面が凹んで底が硬い, 又キョロをふれる。範 } \\
\text { 囲がせまい, たとえ腫れていても経穴部は凹ん } \\
\text { でいる。経穴は温度差が良くわかる。温感, 湿 } \\
\text { 気(汗), 冷感, 乾燥。 } \\
\text { 古典では分肉の間, 脉動ずる中。大筋, ある } \\
\text { いは筋の上。骨の上, 骨の端, 両骨の間。 }\end{array}$ & $\begin{array}{l}\text { 表面が緊張していて底まで硬いこと多し。範囲 } \\
\text { が広い。温度差が少ない。 }\end{array}$ \\
\hline 按す(問診) & $\begin{array}{l}\text { 一般に表面より底に硬さあり。按すと気持ちが } \\
\text { 良い。初め痛くても次第に気持ち良くなる。 }\end{array}$ & $\begin{array}{l}\text { 表面から底まで硬くグリグリしている。痛くて } \\
\text { がまん出来娃もある。始めから終りまで痛い。 }\end{array}$ \\
\hline 前柔法 & $\begin{array}{l}\text { 発赤して周囲も軟かくなり経穴は充実して来る。 } \\
\text { 何回さわっても部位の移動がない。 }\end{array}$ & $\begin{array}{l}\text { 発赤はするが凝りがますます硬くなる場合と, } \\
\text { 凝りがとけた場合は次回さわったら部位が移動 } \\
\text { している。 }\end{array}$ \\
\hline 刺針 & $\begin{array}{l}\text { 大変刺し易く，しばらくそのままに保持すると } \\
\text { 充実感あり (古典でいう気血充実)。周囲の筋皮 } \\
\text { 膚もやわらかくなり弾力が出来る。 }\end{array}$ & $\begin{array}{l}\text { 刺しにくく硬結がとけずに太くなる場合が多い。 } \\
\text { 硬結消失に時間かかる。虚弱な場合はとけるが } \\
\text { 周囲に対してあまり変化ない。 }\end{array}$ \\
\hline $\begin{array}{l}\text { 問診 } \\
\text { (患者に) }\end{array}$ & $\begin{array}{l}\text { 刺されて気持ちが良く刺痛が少ない。抜刺して } \\
\text { のち体が温まる。その時痛みは消えないが, 後 } \\
\text { になって痛みが消えて体調良くなる。 }\end{array}$ & $\begin{array}{l}\text { 刺してもらって痛いこと多い。痛みは即消えた } \\
\text { 様に思えるがすぐ又痛みはじめ, 時には以前よ } \\
\text { り余計に痛むことあり, 体がだるい疲れてしん } \\
\text { どい。 }\end{array}$ \\
\hline
\end{tabular}

(2)経穴と非経穴の違い

\begin{tabular}{|c|c|c|}
\hline & 経 & 穴（圧痛点） \\
\hline 施尒 & $\begin{array}{l}\text { (問診) 熱くなく気持ちが良い。壮数重ねるほど } \\
\text { 良い。 }\end{array}$ & $\begin{array}{l}\text { 割合に熱い。壮数重ねても熱さはやわらがない。 } \\
\text { 次第に熱くなって，すえられない。 }\end{array}$ \\
\hline 治療経過 & 治りが早く, 治療作用長く続く。 & $\begin{array}{l}\text { 効果ある様に見えるが良くならない。治療作用 } \\
\text { 続かない。 }\end{array}$ \\
\hline 経穴 & $\begin{array}{l}\text { 機能的変化(気虚) } \\
\text { 神経痛, 大筋小筋上に，又は関節周辺等に，緊 } \\
\text { 張膨隆した状態で表われるが，穴の部位はやや } \\
\text { 凹んでいる場合が多い。 }\end{array}$ & $\begin{array}{l}\text { 器質的変化 (血虚) } \\
\text { リウマチ，筋肉の間，関節部に凹んで現われ， } \\
\text { 表面硬い場合と，底が硬い場合がある。 }\end{array}$ \\
\hline
\end{tabular}


経穴

経穴とは, 今日まで学んだ経穴部位を, 見て触っての感覚で次の様に分類してみました。

\begin{tabular}{|c|c|c|c|c|c|c|c|c|c|}
\hline & 新 & L & $w$ & 病 & 久 & L & , & & 病 \\
\hline 硬結 & \multicolumn{4}{|c|}{$\begin{array}{l}\text { 按して表面から底まで硬いものと, 表面が硬く } \\
\text { 底が軟いもの等がある。大きさはアワッブ大か } \\
\text { ら小豆大である。棒状に筋緊張膨隆があっても } \\
\text { 穴と思われる部位はやや陌凹している（凹んで } \\
\text { いるのは栄養障害である)。 }\end{array}$} & \multicolumn{5}{|c|}{$\begin{array}{l}\text { 按してみると凹んで底にアワッブ大のキョロを } \\
\text { 触れる。筋弛緩してぶよぶよと軟弱で力がない } \\
\text { 大きさは小豆大か指頭大である。凹んだ皮䖉に } \\
\text { は乾燥していてうるおいがない。表面も底もや } \\
\text { わらかく中間に硬いものを触れる。 }\end{array}$} \\
\hline $\begin{array}{r}\text { 温度 } \\
\text { 色 } \\
\text { 脉 }\end{array}$ & \multicolumn{4}{|c|}{$\begin{array}{l}\text { 熱気あり。 } \\
\text { 赤黄味, 血絡(赤)。 } \\
\text { 脉動じている。 }\end{array}$} & \multicolumn{5}{|c|}{$\begin{array}{l}\text { 冷気湿気あり。 } \\
\text { 青白い。血絡(どす黒い)。脉動じ方少ない。 }\end{array}$} \\
\hline $\begin{array}{l}\text { 問診による } \\
\text { (圧痛) }\end{array}$ & \multicolumn{4}{|c|}{$\begin{array}{l}\text { 按すと知覚過敏で飛びあがる様に痛むものから, } \\
\text { やや痛むもの, 気持ち悪いもの。按して初めは } \\
\text { 痛みをきつく感じるが按すほどに痛みやわらぐ } \\
\text { (全体的に浅く現われる)。 }\end{array}$} & \multicolumn{5}{|c|}{$\begin{array}{l}\text { 按すと知覚鈍麻で気持ちの良い痛みである。抬 } \\
\text { して初めは痛みを感じないが次第に痛みを感し } \\
\text { るようになる。(全体的に深い部に多い)。 }\end{array}$} \\
\hline
\end{tabular}

(臨床上)古典より病因分類した場合

我々の治療室における患者の大半は痛みを訴之てい る。その痛みを古典的に分類してみますと（実際に臨 床にこの方法を用いているものですから），

○痛みの病因となる外邪は風寒湿である

風寒湿の三邪の内，風邪の優るものを風瘇といい，寒 邪の優るものを寒痺といい, 湿邪の優るものを湿痺と いう。

これらの症状を示した時の経穴の有り方は次の様であ る。

風猈は痛みが走る。経穴に触れてみると膨隆していて その中心が凹んでいることが多い。

患者は按すと大変痛いという。押しつつけると痛み

やわらぐ，指を離すと痛みも消失する場合が多い。

寒瘏は痛み移動せず一定部に停滞している。経穴も大

変凹んで底にキョロをふれる

患者は按すと痛がるがしばらく押していると痛みや わらぐ。指を離しても痛みは全く変らず，時には痛 み增す場合がある。温めると痛みやわらぐ。

湿痺は痛みとしびれが合併し経穴は凹んでいる場合が 多く, 表面は大変軟かく底に硬いものを触れる。 患者は押していると大变気持ちが良いという。押し ていると痛みが止まり指を離すとその周囲に温感を 覚えるが痛みは変らない。時にはしびれのみ残るこ ともある。

\section{古典の結論 現代医学的結論}

古典的

古書にあるごとく, 分肉の間赤白肉の際, 約文中, 脉動する所, 爪角を去る菲葉の如き言葉をもって示 しているが, 筋溝とか関節, 腱の際, あるいは脉動 部にあり。陥凹しており，硬結，圧痛をもっている。 現代医学的には

リンパ循環ではないかとも思える。経絡を含めての 運動反射・痛覚反射・栄養反射。中国では, 血管の 分岐部に経穴が存在しているといっている。自律神 経の働きが関与している。

(厂794 愛媛県今治市北日吉町1-2-18) 


\section{II-2 経穴について}

（1）これ等の総べての硬結の辺縁が，経絡線と４ケ所 に交はる，その点に 4 個の経穴が存在する。

（2）以上の経絡線を前腕でみると，この様になります。
経穴だけに就いて，話をせよとの御注文でしたが， 私の研究では, 経絡に依って経穴が違った様子をして 居ります。

肺経は盘地状硬結であって，その経穴は皮痛面から 陷没して居ます。これに反して大腸経は同じく，円形 状の硬結であるが, 皮膚上に求心状に隆起して居りま す。

足の胃経は，硬い経絡線上に在り，大腸経と同じく， 皮覤表面に隆起して居ますが，その隆起は中央が河川 状に，陥没して，周囲に土手の様になって居ます。そ の河川状硬結の中央の陥没線状に, 潜在丘疹がある。

足の脾経も又肺経と同じく，円形の盆地状硬結か， 皮䖉表面から陷没して居る。

手の心経は溝状硬結で, 表面から見ると長方形であ る。

手の小腸経も亦表面からみると長方形で，力マボコ 状に隆起し, カマボコ型硬結とでも称す可きものであ る。

心経・小腸経は共に長方形の中心点に潜在丘疹があ る。

足の膀胱経は, 橋状硬結とも書きましたが, 円形硬 結で，表面から見ると円形であるが，その硬結は大腸 経より大であり，経絡線上更に 2 段に隆起し，横断面 でみると乳房状に隆起して居る。

足の腎経は表面からみると，紡錐をつなぎ合せた様 な形をして, 経絡線上の部分たけ陷没し, 経絡線外の 所は隆起して居る，その紡錐の中央に潜在丘疹がある。

手の劂陰心包経の経絡線は矩形を，つなぎ合せた様 になって居て, この部は陷没し, 矩形の短経に一致し て, 円形の硬結があって,この円形の硬穴は隆起し, この円形硬結の中央に潜在丘疹がある。

手の少陽三焦経は, 河川状に隆起し, その中央に河 川状の陷没した線があり，その陷没線の中に矩形の陰 性硬結があり，その矩形の中央に潜在丘疹がある。

足の少陽胆経は, 楕円形硬結で, 皮虞表面に隆起し て居る。この楕円形の硬結の間に, 小楕円形が経絡線 に一致して存在する。大楕円形の中央に潜在丘疹があ る。

足の㷧㓌肝経は, 表面からみた場合, 胆経と殆ど同 じ，但し胆経と異なって，皮膚表面から陥没して居る。

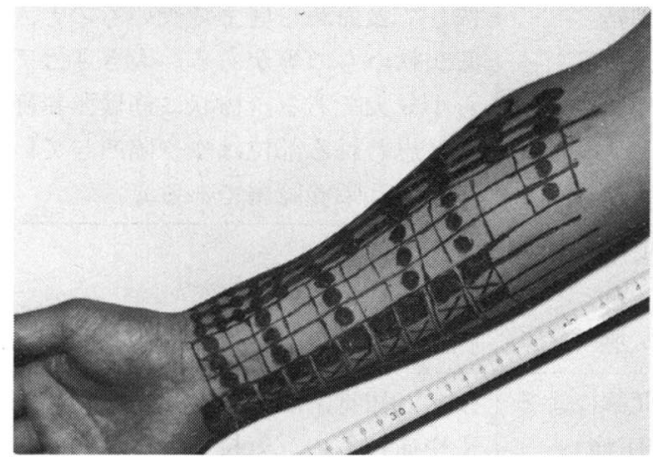

図1肺経・心包経・心経の経絡と経穴 を示す

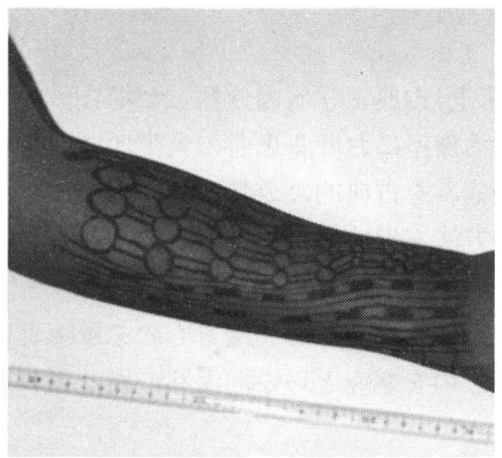

図2 肺経・大腸経・三焦経・小腸経の 一部の経絡と経穴を示す

(3) 顔面の経穴

顔面で最も著明な経穴は, 素䯎(督脈)であり, その 外に糸竹空(三焦経)，顴髎(小腸経）に4 個の経穴が あり, 鼻の経穴は周囲の 4 個の娘反応点があり, 目は 瞳孔の中央に主反応点があり, 周囲に 4 個の娘反応が ある。眉毛にも五個の経穴があり， 口にも龈交(督脈) を中心に, 五個の経穴が存在する。頭では, 百会(督 脈）を中心に，五個の経穴が存在する。聴宮(小腸経) にも五個の経穴があり，耳後にも五簓の経穴がある。

同様にして乳房・胎部にも五筒の経穴があり，陰部 にも五筒の経究がある。

この娘反応点の周囲に 4 個の娘反応点が出来て, 更 に其の反応点の周囲に 4 筒の娘反応点が発生し, 漸次 無数の反応点に移行する。

( (923 石川県小松市中町6) 


\section{II-3「臨床経験より見た経穴について」}

一経穴部の所見は? 非穴部との相違点は？一

東洋はり医学会会長 福島 弘道

1972年の中国における鍼麻酔を契機に，全国的，全 世界的に多彩な銊法が行われ，それぞれ或程度の臨床 成績を挙げている。

従って,「治療経験より見た」といっても，その治療 方式により臨床実技は頗る多様多彩である。従ってこ のような背景によって行われている，鍼炎術の施術点 である経穴の部位や取穴法等を統一しようとしても， 大きな難問に突きあたるのは理の当然である。

近時, WHOの主催による「国際経穴委員会」なる 機関が，この不可能な難問を可能にすべく努力してお られるが，私としては荷担しかねる次第である。

さて，このような背景を考えながら，我々東洋はり 医学会においては，生きて働いている経穴の取り方に ついて集団研究を進めているが勿論本会の行う銊法は, 経絡治療であるから, 当然その治療方式に合致した取 穴をすることになる。そこでまず，経絡治療の方式に ついて少し述べる必要がある。

即ち，経絡治療とは「病態を気血の変動として総合 的に観察し，すべての病症を経絡の虚実として把握し， その主たる変動経絡を主証とし，その経穴を診断と治 療の場として, 鍼尒をもって補瀉調整し, その生命力 を強化する随証治療」である。

即ち, 経絡治療の理念は, 生命力の強化, 気を調之 ることであり, 変動経絡の調整である。従ってその用 鍼は, 1 番ないし 3 番の細鍼で, その刺銊深度も殆ど 接触鍼か，深くても $5 ， 6$ ミリに過ぎないのである。

従って,このような臨床体験よりえたる取穴法は, いわゆる刺激理論に基づく鍼炎術とは大いに異なるこ とを，まず強調しておかなければならない。

さて，かくの如き観点に立つ我々の取穴法には，一 種独特の方法があるのである。即ち, 江戸初期の後藤 艮山は「穴はなおる所でも，効く所でもない。その治 療家が効かす所，なおす所である」と厳しく諭している。 この訓言に正しく従う臨床実践をするためには，澤 田健のいう如く「生きた穴と死んだ穴を取り分ける」 のでなければ，好成績を挙げることは出来ない。

そこで本会では, その集団研修を進める中で, 数年 前より「生きて働いている穴の取り方」について，取 穴法の修練を行っている。これは要するに，取穴法に
おける指頭感覚の厳しい訓練であると考える。

研ぎ澄ました如き熟達した治療家の鋭い指頭は，何 寸何分とか，何センチなどと寸法にとらわれることな く，今生きて働いている究に吸い寄せられて，どんぴ しゃりと穴をおさえ，適確な施術をすることが出来る のである。

そこでその取穴訓練法であるが，そのためにはまず 経絡治療に合致したモデル点，いわゆる最も一般的な 穴位を基礎に行われるが，この経穴書としては，かっ て本会顧問の西村至央氏の講義に基づいた「要穴の部 位とその取り方」に準拠して行っている。

具体的にその実際について述べると，まずモデル患 者の表す主証に基づき，その要穴点に極めて静かに鍉 鍼を接触すると，その影響は瞬間的に六部定位の䐂と， 経絡腹証にプラス，マイナスが現れるので，これを目 標に仮点し，瞑目してその穴位を触察しながら，経穴 部の特異な所見や，非穴部との相違を観察しつつ，指 頭訓練を積み重ねている。

更には、こうしてとらえた今生きて動いている穴に 刺鍼して，その適否を観察する，というように単なる 机上の空理空論ではなく，臨床に直結した取穴法の修 練をするのが本会の特徵である。このような修練を我 々は「経絡経穴を患者の体に学ぶ」といっている。

最後に表題である経穴部の所見，並びに非穴部との 相違について結論を書いておく。

経穴とは, 霊枢九銊十二原篇に,「生気, 真気の遊行出 入する所なり。皮肉筋骨に非ず」と言明している。一 般に圧痛, 硬結緊張して発赤, 腫脹して熱するを実と し，陷下，鈍麻して冷え，痺れるを虚とするが，最も 一般的な経穴点は, 直径 4,5 ミリないし 1 ミリ位で, 中央がややぶよぶよして抵抗が減弱し，中に瘀血の流 滞を感ずるものである。当然, 周囲より生気が失われ ている。

例えばりんごを床にコツンとあて，数時間後にこれ を触察すると，その部がわづかにぶよぶよと抵抗が減 弱し，生気が失われている。ついでに生気の観察につ いて，生きて働いている組織はさながら春の若芽の如 く，菲の葉のようであるが，生気を失った病的な所見 は, 秋の枯葉の如くうるおいと艶が減弱し，かたく感 ずる。

以上，わずかに限られた紙数であるので，甚だ粗雑 なまとめとなったが, 要は繰り返し繰り返し, 治療家 の指頭訓練を積み重ねるということに尽きるであろう。

（干160 東京都新宿区新宿7-2-17） 